\title{
Antigen presentation in the gut
}

W DOE, MB, MSC, FRCP, FRACP, P PAVLI, MB,BS, FRACP

\begin{abstract}
The induction of $T$ cell responses requires recognition of antigens in association with class II major histocompatibility complex (MHC) proteins and specialized antigen-presenting cells. Candidate antigen-presenting cells in the gut include dendritic cells, macrophages, B lymphocytes, mucosal epithelial cells and endothelial cells. Dendritic cells isolated from normal human colon are potent inducers of primary immune responses and express high levels of class II MHC proteins. Lamina propria macrophages display class II MHC proteins, can present antigens to sensitized $T$ cells, may process antigen and release interleukin-1, but suppress antigen presentation by intestinal dendritic cells in a dose-dependent manner. Class II MHC molecules are normally expressed on small intestinal epithelial cells but not on normal colonic epithelial cells. Suppressor $T$ cells and unresponsive $T$ helper cells in the mucosa appear to mediate systemic $T$ cell tolerance of dietary antigens. In the inflamed colon there is infiltration of the lamina propria by large numbers of monocytes which secrete interleukin-1, and the release of interferon-gamma appears to induce class II protein expression on colonic epithelial cells. Colonic epithelial cells from inflamed bowel may preferentially stimulate Thelper cells so that local induction of class II MHC molecules on epithelial cells may amplify and localize secondary immune responses at the site of inflamed mucosa. Taken together, the aberrant expression of class II MHC molecules, breaches in epithelial cell integrity (resulting in exposure to luminal antigens including endotoxin) and the increased numbers of monocytes found in inflamed mucosa suggest that the resulting distortions in antigen presentation contribute to the localization and persistence of the inflammatory lesion in inflammatory bowel disease. Can J Gastroenterol 1990;4(7):267-270 (pour résumé, voir page 268)
\end{abstract}

Key Words: Etiology, Immunology, Inflammatory bowel disease

Division of Clinical Sciences, John Curtin School of Medical Research, Australian National University, Canberra City, Australia

Correspondence and reprints: Professor W Doe, Division of Clinical Sciences, John Curtin School of Medical Research, Australian National University, PO Box 334, Canberra City, ACT, 2601, Australia. Telephone 61-6-249 2392, Fax 61-6-249 0413
A NTIGEN PRESENTATION INVOLVES the denaturation of native antigen and the display of the processed antigen on the surface of specialized antigen-presenting cells in association with proteins of the class II major histocompatibility complex (MHC). When a resting $\mathrm{T}$ lymphocyte comes into contact for the first time with its cognate antigen presented in association with self $\mathrm{MHC}$ molecules, $\mathrm{T}$ cell activation occurs. By contrast, a secondary immune response is triggered by antigen presented in association with class II $\mathrm{MHC}$ molecules to $\mathrm{T}$ cells which have previously been exposed to that antigen. Activation requirements for resting and memory $T$ cells differ from those of sensitized or activated $T$ cells (1). The principal roles for accessory cells in the primary immune response comprise the presentation of antigen in association with class II MHC gene products to form a complex on the surface of the antigen-presenting cell that can be recognized by an antigenspecific clonotypic $\mathrm{T}$ cell receptor, and the delivery of an unidentified second signal to initiate $\mathrm{T}$ cell blast transformation, interleukin-2 secretion and clonal proliferation. By contrast, the 


\section{Présentation de l'antigène dans l'intestin}

RESUME: Les réponses immunes à médiation cellulaire T exigent la reconnaissance de l'antigène, le complexe d'histocompatibilité $(\mathrm{CMH})$ et les cellules spécialisées présentant l'antigène. Les cellules pouvant remplir ce rôle au niveau de l'intestin sont les cellules dendritiques, les macrophages, les lymphocytes B, les cellules muqueuses épithéliales et endothéliales. Les cellules dendritiques isolées du côlon humain normal sont des inducteurs puissants des réponses immunitaires primaires et elles produisent des taux élevés de protéines $\mathrm{CMH}$ de classe II. Les macrophages de la lamina propria présentent des protéines $\mathrm{CMH}$ de classe II, peuvent présenter des antigènes aux cellules T sensibilisés, traiter les antigènes et libérer de l'interleukine-1, mais ils peuvent supprimer la présentation de l'antigène par les cellules dendritiques intestinales en fonction de la dose. Les molécules $\mathrm{CMH}$ de classe II sont normalement exprimées sur les cellules épithéliales du grêle mais non pas sur les cellules épithéliales normales du côlon. Les cellules suppressives $T$ et les cellules helper $T$ qui ne réagissent pas semblent orchestrer la tolérance systémique des cellules $T$ aux antigènes alimentaires. Dans le côlon enflammé, la lamina propria est infiltrée par de nombreux monocytes qui secrètent l'interleukine-1, et la libération de l'interféron-gamma semble déclencher l'expression des protéines de classe II sur les cellules épithéliales du côlon. Les cellules épithéliales coliques provenant de l'intestin irrité pourraient stimuler les cellules helper $T$ de façon telle que l'induction locale de molécules $\mathrm{CMH}$ de classe II amplifie et localise les réponses immunitaires secondaires au site de la muqueuse inflammée. Si l'on considère à la fois l'expression aberrante des molécules CHM de classe II, l'intégrité lésée des cellules épithéliales (qui entraîne l'exposition aux antigènes de la lumière, y compris aux endotoxines) et l'augmentation du nombre des monocytes présents dans la muqueuse, on peut conclure que les distortions qui surviennent dans la présentation des antigènes contribuent à la localisation et à la persistence des lésions inflammatoires des MII.

sensitized $\mathrm{T}$ cell does not require the second signal and responds vigorously to the presentation of the antigenMHC complex alone. The magnitude of the secondary response depends upon the concentration of antigen and the surface density of class II MHC molecules on the antigen-presenting cell.

\section{INTESTINAL ANTIGEN UPTAKE}

The mucosal surface of the gut is exposed to a vast array of antigens, including products of food digestion, microorganisms and drugs, yet hypersensitivity reactions to dietary antigens are uncommon. In the small intestine, the preferential site of antigen uptake appears to be Peyer's patches where the specialized epithelium contains M (for 'membranous') cells that transport soluble and particulate antigens intact across the epithelium to the lymphoreticular cells of the dome region of the patch (2). Antigen can also cross the intact mucosal epithelium by entering the lamina propria between epithelial cells, by persorption (the passage of macromolecules or small particles by kneading between epithelial cells), by villous uptake through the extrusion zone when epithelial cells are shed from the villous tip, and by active uptake through the epithelial cell by endocytosis or by a receptor-mediated mechanism (3).

\section{ANTIGEN-PRESENTING CELLS IN THE INTESTINE}

Cell types that express class II MHC molecules have the potential to present antigen in some circumstances. The candidate antigen-presenting cells in the gut include dendritic cells, macrophages, B lymphocytes, mucosal epithelial cells and endothelial cells.

Dendritic cells isolated from the human colon have the characteristic morphology and properties of splenic dendritic cells. They are large irregular cells that display typical membrane folds or veils, are nonadherent and nonphagocytic and lack the enzyme markers, surface receptors and antigens that characterize macrophages, $T$ cells and B cells. After antigen exposure, dendritic cells migrate as 'veiled cells' in the afferent lymphatics to regional lymph nodes where they become the interdigitating cells of the paracortex. Here they interact with $T$ cells bearing the specific antigen receptor to initiate the immune response. Dendritic cells are specialized antigen-presenting cells which can induce primary $\mathrm{T}$ lymphocyte responses to both soluble and particulate antigens and exhibit a unique ability to form clusters with resting $T$ and $\mathrm{B}$ cells - a phenomenon important to the induction of the primary response. Dendritic cells from Peyer's patches, but not from the spleen, preferentially induce polyclonal $\operatorname{IgA}$ responses when mixed with $B$ cells from either Peyer's patch or the spleen. Interleukin-1 appears to amplify the proliferative response to limiting numbers of dendritic cells, which cluster more efficiently with $T$ cells before the onset of mitogenesis (4). Interleukin-1 also matures dendritic cell precursors and promotes their differentiation into functionally competent antigenpresenting cells.

Over $90 \%$ of the macrophages harvested from normal human colon express class II proteins, equipping them to present antigen (5). Whether lamina propria macrophages can act as antigen-presenting cells and induce a primary immune response, however, is doubtful because they have been shown to suppress induction of primary im. mune responses by intestinal dendritic cells, an action mediated by prostaglandin $E_{2}$ (6). As discussed above, however, intestinal macrophages may be involved in antigen processing, producing interleukin-1 or presenting antigen to sensitized $\mathrm{T}$ cells in certain circumstances, but whether macrophages are required for antigen processing or as a source of interleukin-1 is uncertain.

Activated but not resting B cells can also take up antigen using specific surface immunoglobulin receptors. B cells process antigen which can be displayed complexed to class II MHC molecules. Although activated B cells can form clusters with $T$ cells, they are dependent on the leukcyte function antigen-1 molecule for cell-to-cell adhesion (7). Because only activated B cells can sen- 
sitize $\mathrm{T}$ cells, the role of $\mathrm{B}$ cells as antigen-presenting cells appears confined to secondary immune responses.

Class II MHC molecules are also expressed on the basolateral membrane and apical surface of mature epithelial cells of the small intestine and on the epithelium of Peyer's patches, but these molecules are not found on stomach or colon epithelial cells unless they are directly associated with lymphoid follicles (8). Class II MHC molecules may be involved in the absorption of luminal macromolecules across the epithelium in a manner analogous to that suggested for class I MHC type molecules in mediating the uptake of $\operatorname{IgG}$ from maternal milk $(9,10)$. Such involvement would suggest a genetically restricted, class II-dependent transportation and presentation of luminal antigen to intra-epithelial lymphocytes or to the cells of the lamina propria.

\section{INDUCTION OF INTESTINAL IMMUNE RESPONSES}

While the intestinal immune system can mount effective responses to potential pathogens such as viruses, bacteria and parasites, soluble dietary antigens evoke little reaction. Secretory $\operatorname{Ig} \mathrm{A}$ antibody responses occur but usually a state of immunological tolerance develops locally and systemically so that hypersensitivity reactions to dietary proteins are very uncommon. A single exposure to fed antigen can suppress both antibody- (especially $\operatorname{IgE}$ class) and cell-mediated immune responses to that specific antigen for up to two years. This state of specific immunological unresponsiveness induced by oral feeding is called 'oral tolerance'.

Although the immunoregulation of oral tolerance is complex, $\mathrm{T}$ cells appear to play a central role. Suppressor T cells appear to mediate tolerance of systemic cell-mediated immune responses, whereas tolerance of systemic antibody responses has been attributed to $\mathrm{T}$ helper cell anergy (11).

\section{ANTIGEN HANDLING IN IBD}

The inflammatory lesion of IBD allows massive exposure of the intestinal lamina propria to luminal antigens and to highly biologically active products of commensal bacteria such as endotoxin. The destruction of epithelial integrity results in a loss of control of antigen entry across the epithelium so that the intestinal immune system that suppresses local and systemic immune responses to soluble antigens is compromised. The heavy inflammatory cell infiltrate includes a large population of monocytes which turn over rapidly in actively inflamed areas; this has been shown by scans using radiolabelled autologous monocytes (12). These monocytes represent an active population of cells that have the potential to present antigen and produce markedly enhanced amounts of interleukin-1 $(13,14)$, resulting in further monocyte activation and stimulation of $T$ cell cytokine production.

Abnormal expression of class II $\mathrm{MHC}$ proteins occurs in regions of active IBD. There is increased expression of class II antigens by epithelial cells in the small intestine and de novo expression in colonic epithelium. Class II expression appears to be induced by interferon-gamma and its expression on small intestinal epithelial cells may be modulated by intra-epithelial lymphocytes (15). The significance of aberrant expression of class II molecules in colonic epithelial cells in IBD is uncertain, but the question arises as to whether this phenomenon allows colonic epithelial cells to present antigen and induce abnormal immune re. sponses that contribute to inflammation and tissue injury. Isolated rat enterocytes cultured with sensitized lymph node-derived $\mathrm{T}$ cells did not stimulate proliferation in the presence of antigen. Rather, the results indicated that antigen-specific suppression occurred which was blocked by antibodies to class II MHC antigens, suggesting that epithelial cell presentation of antigen to the intra-epithelial lymphocyte presented a possible means of inducing oral tolerance in the normal small intestine (16). Expression of class II MHC molecules on colon epithelial cells during inflammatory responses, however, may trigger aberrant immune responses (17). There is evidence that colonic epithelial cells from active IBD bowel may present antigen and preferentially stimulate $\mathrm{T}$ helper cells, providing a further mechanism for amplifying and localizing immunemediated tissue injury (17). On the other hand, the expression of class II MHC proteins on the epithelial cell may simply reflect the presence of increased levels of interferon-gamma produced by the inflammatory $\mathrm{T}$ cell infiltrate. Thus, rather than initiating $T$ cell responses, the aberrant expression of class II MHC determinants would then serve to focus the effector functions of previously sensitized T cells to the site of antigen entry.

Taken together, the breaches in epithelial integrity in IBD that lead to exposure to luminal antigens and bacterial products result in greatly increased numbers of monocytes in the IBD mucosa with resulting enhanced production of interleukin-1, interferon-gamma and aberrant expression of class II MHC molecules on colonic epithelial cells. These distortions of antigen presentation in IBD-affected mucosa may contribute significantly to the localization and persistence of mucosal inflammation.

\section{REFERENCES}

1. Steinman RM. Cytokines amplify the function of accessory cells. Immunol Lett 1988;17:197-202.

2. Wolf JL. The membranous epithelial (M) cell: A portal of entry. In: Kirsner JB, Shorter RG, eds. Inflammatory Bowel Disease. Philadelphia: Lea \& Febiger, 1988.

3. Nicklin S. Intestinal uptake of antigen - Immunological consequences. In: Miller IK, Nicklin S, eds. Immunology of the Gastrointestinal Tract. Boca Raton: CRC Press, 1987:87-109.

4. Koide SL, Inaba K, Steinman RM. Interleukin-1 enhances T dependent immune responses by amplifying the function of dendritic cells. J Exp Med 1987;165:515-30.

5. Golder JP, Doe WF. Isolation and preliminary characterization of human intestinal macrophages. Gastroenterology 1983;84:795-802.

6. Pavli P, Woodhams CE, Doe WF, Hume DA. Isolation and characterization of antigen-presenting dendritic cells from the mouse intestinal lamina propria. Immunology 1990;70:40-7.

7. Metlay JP, Pure E, Steinman RM. Control of immune responses at the level of antigen-presenting cells: A comparison 
of the function of dendritic cells and B lymphocytes. Adv Immunol 1989;47:45-116.

8. Scott H, Solheim BG, Brandtzaeg P, Thorsby E. HLA-DR-like antigens in the epithelium of the human small intestine. Scand J Immunol 1980;12:77-82.

9. Simister NE, Mostov KE. An Fc receptor structurally related to MHC class I antigens. Nature 1989;337:184-7.

10. Mayrhofer G, Pugh CW, Barclay AN. The distribution, ontogeny and origin in the rat of Ia positive cells with dendritic morphology and of la antigen in epithelia, with special reference to the intestine. Eur J Immunol 1983;13:112-22.
11. Mowat AMcI. The regulation of immune responses to dietary protein antigens. Immunol Today 1987;8:93-8.

12. Pullman WE. Analysis of leukocyte functions in inflammatory bowel disesase. Canberra, ACT, Australia: Austrialia National University. PhD Thesis 1989.

13. Pullman W, Elsbury S, Hapel A, Doe WF. Colony stimulating factor production by intestinal lamina propria cells is increased in inflammatory bowel disease. Gastroenterology 1988;94:A361.

14. Mahida YR, Wu K, Jewell DP. Enhanced production of interleukin 1. $\beta$ by mononuclear cells isolated from mucosa with active ulcerative colitis or Crohn's disease. Gut 1989;30:835-8.

15. Cerf-Bensussan N, Quaroni A, Kurnick JT, Bhan AK. Intraepithelial lymphocytes modulate Ia expression by intestinal epithelial cells. J Immunol 1984;132:2244-52.

16. Bland PW, Warren LG. Antigen presentation by epithelial cells of the rat small intestine. II. Selective induction of suppressor T cells. Immunology 1986;58:8-14.

17. Mayer L, Eisenhardt D. Lack of induction of suppressor $\mathrm{T}$ cells by gut epithelial cells from patients with inflammatory bowel disease. The primary defect? Gastroenterology 1987;92:1524. 


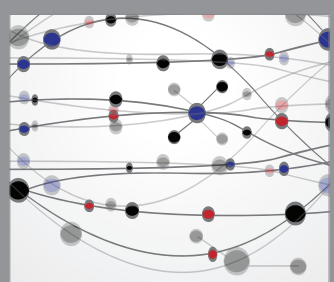

The Scientific World Journal
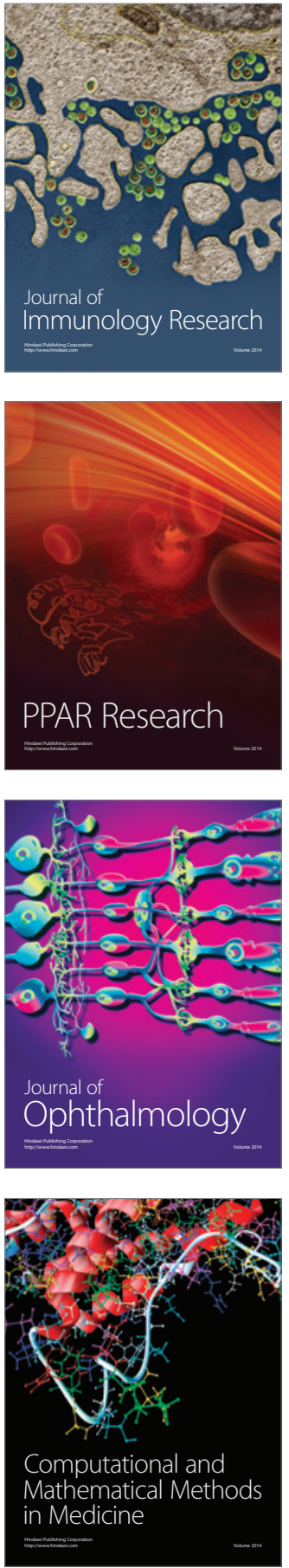

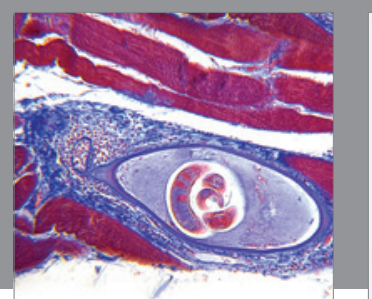

Gastroenterology Research and Practice

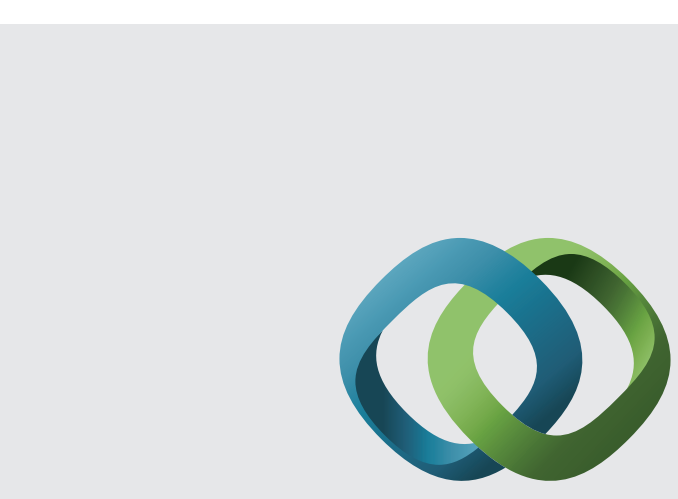

\section{Hindawi}

Submit your manuscripts at

http://www.hindawi.com
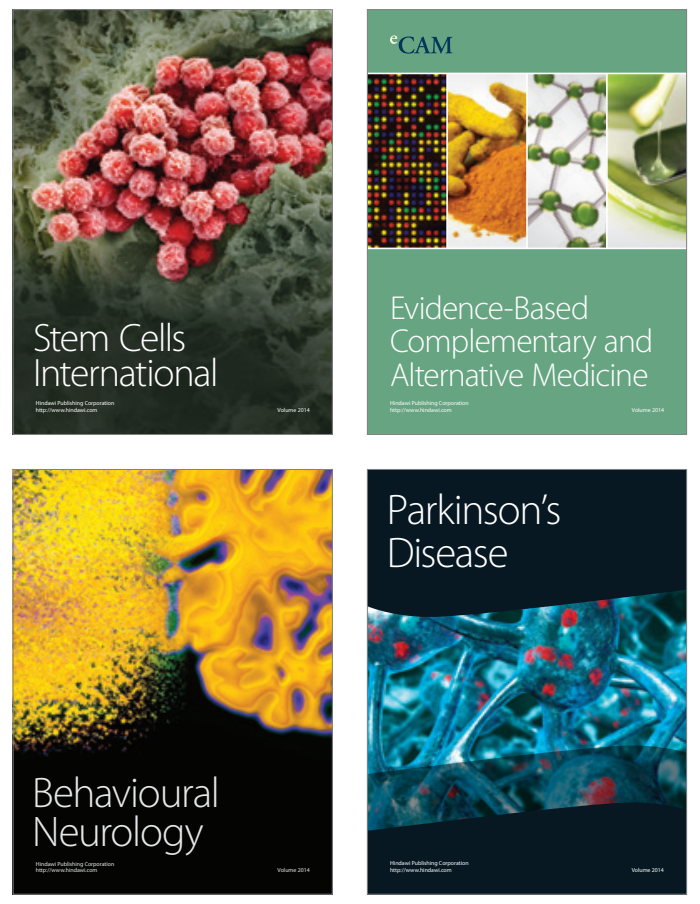
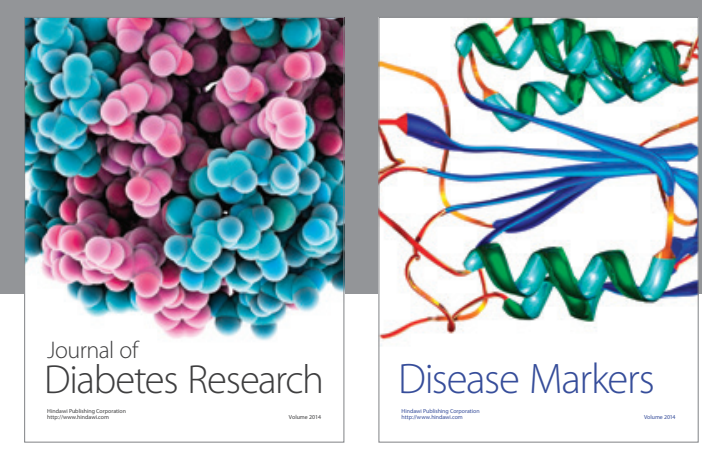

Disease Markers
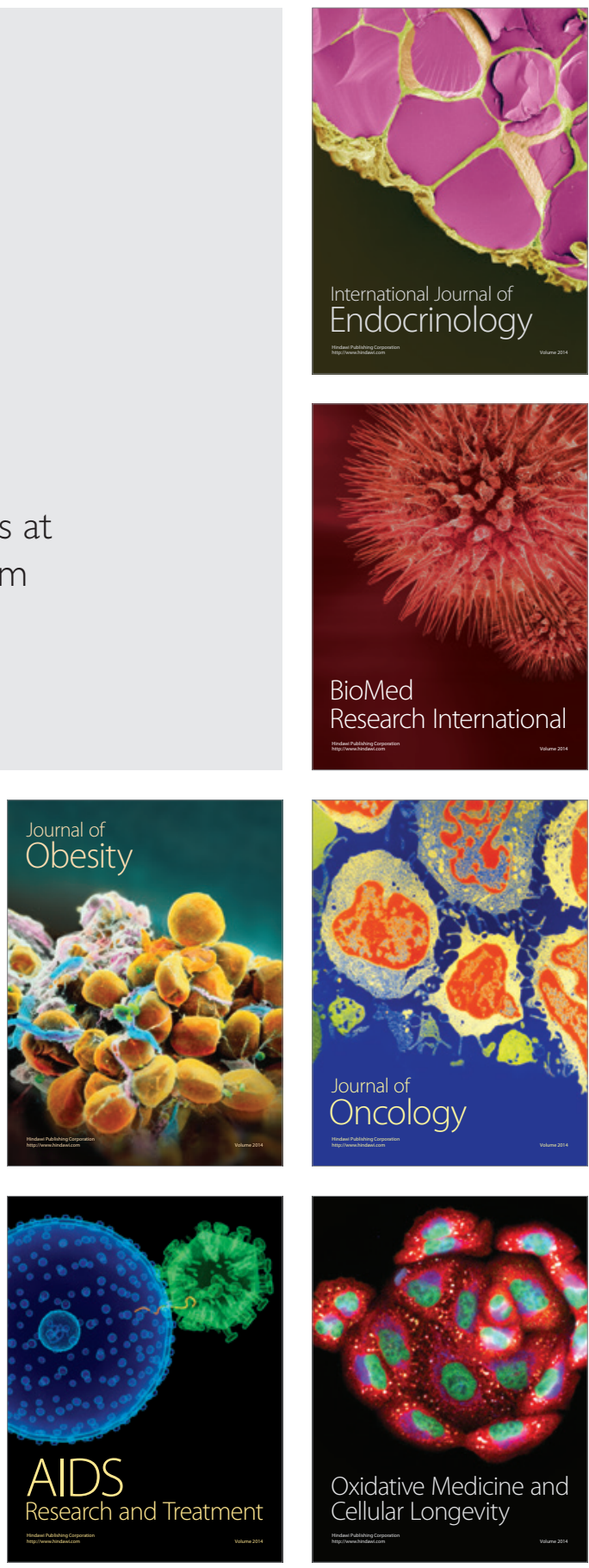